\title{
Is Genomic Selection Viable for Dairy Goats in Developing Countries?
}

\author{
Diego Rodrigues de Sousa ${ }^{2}$ and Raimundo Nonato Braga Lobo ${ }^{1 *}$ \\ ${ }^{1}$ Animal Breeder Research,Brazilian Agricultural Research Corporation, Embrapa Caprinos e Ovinos, Brazil \\ ${ }^{2}$ PhD Student, Departamento de Zootecnia, Universidade Federal do Ceará, Brazil
}

Submission: March 01, 2019; Published: March 08, 2019

*Corresponding author: Raimundo Nonato Braga Lobo, Animal Breeder Research - Brazilian Agricultural Research Corporation - Embrapa Caprinos e Ovinos, Estrada Sobral/Groaíras, km 04, Caixa postal 71, Sobral 62010-970, CE, Brazil / CNPq PQ Scholarship

\begin{abstract}
The linkage disequilibrium (DL) measures the degree of association between alleles on the same chromosomes or on different chromosomes. If there are higher frequencies in these associations, it is indicated that these genes are linked and some serve as markers for others. In this way, it is possible to make selection of genes of economic importance based on the frequency of others that are linked to them. LD forms mainly in the evolutionary process of and animal population selection. Studies showed that dairy goat population in many parts of the world have low DL. Thus, the selection process in these populations was not of intensity to promote high LD. We can stress that selection by molecular markers would produce inefficient results in these population, especially in developing countries with informal dairy goats' market, and the high cost for animal genotyping would not be justified at this time.
\end{abstract}

Abbreviations: GS: Genomic Selection; LD: Linkage Disequilibrium; QTL: Quantitative Trait Loci; SNP: Single Nucleotide Polymorphisms; GEBV: Genomic Breeding Values; MAF: Minor Allele Frequency

\section{Introduction}

Genomic selection (GS) is a strategy that uses molecular markers to predict the breeding values of individuals [1]. In GS, markers scattered throughout the genome are used and their effects are estimated in a reference population that has phenotype and genotype known [2,3]. The rationale behind this process is that whenever the density of the marker panels is high enough, each quantitative trait loci (QTL) that affects a trait will be in linkage disequilibrium (LD) with at least one single nucleotide polymorphisms (SNP) marker, and the estimation of the markers' effects will lead to accurate prediction of merit $[4,5]$. Therefore, the success of GS depends on the existence of LD between markers and QTL across the population of interest [2]. The higher the level of LD, the more precisely the markers can be used to predict the effects of QTL, since there will be greater certainty that the alleles are predicted correctly, consequently the estimates of genomic breeding values (GEBV) can be predicted with greater accuracy [4,5].

Among the statistical measures most used in LD studies for biallelic markers, such SNP, are correlation coefficient between alleles of two loci $\left[\mathrm{r}^{2}, 6\right]$ and standardized value of $D\left|\mathrm{D}^{\prime}\right|[7]$. Some studies $[1,8]$ concluded that $r^{2}$ greater than 0.20 would be sufficient to implement GS. In six goat breeds [9], in the mean distance between adjacent SNPs, in the $50 \mathrm{k}$ SNP panel $(\sim 0.06 \mathrm{Mb})$, most breeds exceeded or approached the recommended value of $\mathrm{r}^{2}$ of 0.20 , except for Alpine and Saanen dairy breeds $\left(\mathrm{r}^{2} \sim\right.$ $0.12-0.13)$. In the dairy goats' French population, $r^{2}$ of 0.17 was reported [10], while a value of 0.18 was estimated for dairy goat's English population [11]. In this later population, only small gains in accuracy in the prediction of GEBV was reported, due to the structure and size of the reference population, which directly influenced the LD levels [11]. We genotyped 948 dairy goats of Saanen breed from herds supported by Programa de Melhoramento Genético de Caprinos Leiteiros - Capragene ${ }^{\circledR}$ / Brazilian Dairy Goats Breeding Program [12], using panel of SNPs Axiom OviCap (Caprine), Affymetrix custom array with 62,557 SNPs. The population evaluated contained 12,226 animals, being 522 sires and 4,091 dams. There were 3,700 animals with performance records, 948 with genotypes, 3,828 with records or genotypes, 128 with genotypes but no records and 8,398 parents without records or genotypes. We estimated $r^{2}$ and $\left|D^{\prime}\right|$ in 0.04 and 0.27 , respectively. The minor allele frequency (MAF) was 0.33 . The LD levels estimated for this population, according to the sample used, demonstrated the need for higher 
SNP densities. At the mean distance between adjacent SNPs, the current $62 \mathrm{k}(\sim 50 \mathrm{~kb})$ SNP panel did not exceed the useful LD $\left(r^{2}>0.20\right)$ for genomic study applications. Thus, better results for this population could be achieved with a denser SNP panel (e.g. $150 \mathrm{k}$ ) and/or larger reference population.

We also estimated GEBV for age at first kidding, kidding interval, lactation length, total milk yield, milk yield up to 305 days, average daily milk yield, total fat yield, total protein yield, total dry matter yield, total lactose yield, total somatic cell count, fat yield up to 305 days, protein yield up to 305 days, dry matter yield up to 305 days, lactose yield up to 305 days, somatic cell count up to 305 days and milk yield / kidding interval. No SNPs with greater effects on the traits evaluated were verified. The genetic variance average by trait explained by the 10 main SNP windows was only $0.05 \%$. Among all the traits, the SNP window that presented the largest genetic variance was found on chromosome 5 and explained $0.17 \%$ of the total genetic variance for somatic cell count up to 305 days. These results confirm, together with the observed to LD, a small selective history in the studied population. We did not observe any haplotype block with a significant effect on the traits studied. There was no way to identify genetic markers for selection based on these results, due to the absence of significant LD, probably because the historical selection process of this population was not of great intensity. The increase of accuracy in the estimate of the breeding values of the animals with genomic information was between $1.62 \%$ and $5.13 \%$, according to the analyzed trait.

Brazil has about 5 million of rural establishments where about 334 thousand have goats but only less than 16 thousand produce goat milk. The per capita consumption of dairy goat products is $0.10 \mathrm{~kg} / \mathrm{inhab} /$ year. Much of the commercialization of dairy goat products is informal and many producers are dependent on a government food purchase program, which has a low quota of acquisition per producer. In this way, the market for goat milk products is complex and of questionable viability, although it is important for the subsistence of poor rural populations. The price of an ordinary Saanen goat (or other specialized breed) is between US $\$ 187$ and US $\$ 268$ and of an improved animal between US $\$ 800$ and US $\$ 1,300$. Thus, with a genotyping price per animal between US $\$ 90$ and US $\$ 100$, the economic viability for genomic selection is called on question in animal populations with low LD and countries with unconsolidated dairy goat market.

\section{Conclusion}

The low linkage disequilibrium observed in many dairy goat populations around the world difficult the application of genomic tools for this specie. The increase in the accuracy of the prediction of the animal breeding values is low and do not justify the costs for genotyping animals in developing countries, where the dairy goat market is informal and incipient. In these countries, genomic applications are important for research studies nevertheless no for commercial purposes.

\section{References}

1. Meuwissen THE, Hayes BJ, Goddard ME (2001) Prediction of total genetic value using genome-wide dense marker maps. Genetics 157: 1819-1829.

2. Goddard ME, Hayes BJ (2007) Genomic selection. Journal of Animal Breeding and Genetics 124: 323-330.

3. Hayes BJ, Bowman PJ, Chamberlain AJ, Goddard ME (2009) Invited review: Genomic selection in dairy cattle: Progress and challenges. Journal of Dairy Science 92: 433-443.

4. Calus MPL, Meuwissen THE, de Roos APW, Veerkamp RF (2008) Accuracy of genomic selection using different methods to define haplotypes. Genetics 178: 553-561.

5. Solberg TR, Sonesson AK, Woolliams JA, Mewissen THE (2008) Genomic selection using different marker types and densities. Journal of Animal Science 86: 2447-2454.

6. Hill WG, Robertson A (1968) Linkage disequilibrium in finite populations. Theoretical and Applied Genetics 38: 226-231.

7. Lewontin RC (1964) The interaction of selection and linkage. I. General considerations; heterotic models. Genetics 49: 49-67.

8. Calus MPL, Meuwissen THE, Windig JJ, Knol EF, Schrooten C, et al. (2009) Effects of the number of markers per haplotype and clustering of haplotypes on the accuracy of QTL mapping and prediction of genomic breeding values. Genetics Selection Evolution 41: 1-10.

9. Brito LF, Jafarikia M, Grossi DA, Kijas JW, Porto-Neto LR, et al. (2015) Characterization of linkage disequilibrium, consistency of gametic phase and admixture in Australian and Canadian goats. BMC Genetics 16: 52-67.

10. Carillier C, Larroque H, Palhière I, Clément V, Rupp R, Robert-Granié C (2013) A first step toward genomic selection in the multi-breed French dairy goat population. Journal of Dairy Science 96: 7294-7305.

11. Mucha S, Mrode R, MacLaren-Lee I, Coffey M, Conington J (2015) Estimation of genomic breeding values for milk yield in UK dairy goats. Journal of Dairy Science 98: 8201-8208.

12. Lôbo RNB, Facó O, Lôbo AMBO, Villela LCV (2010) Brazilian goat breeding programs. Small Ruminant Research 89: 149-154. 

CC This work is licensed under Creative DOI: 10.19080/JDVS.2019.10.555792

\section{Your next submission with Juniper Publishers} will reach you the below assets

- Quality Editorial service

- Swift Peer Review

- Reprints availability

- E-prints Service

- Manuscript Podcast for convenient understanding

- Global attainment for your research

- Manuscript accessibility in different formats

( Pdf, E-pub, Full Text, Audio)

- Unceasing customer service

Track the below URL for one-step submission https://juniperpublishers.com/online-submission.php 